\title{
Recent Advances in Accreditation Systems in Higher Agricultural Educational Institutes (HAEI) in India: A Review
}

\author{
Nimai Chand Patra* \\ Department of Veterinary Pathology, Faculty of Veterinary and Animal Sciences, West Bengal University of Animal and \\ Fishery Sciences, 37, K. B. Sarani, Kolkata, India
}

\begin{abstract}
*Address for Correspondence: : Dr. Nimai Chand Patra, Associate Professor, Department of Veterinary Pathology, Faculty of Veterinary and Animal Sciences, West Bengal University of Animal and Fishery Sciences, Kolkata- 700037, West Bengal, India
\end{abstract}

E-mail: drncpatra@yahoo.co.in

Received: 26 Apr 2021/ Revised: 23 June 2021/ Accepted: 03 Aug 2021

\begin{abstract}
Accreditation is a self-realization and peer review process to improve and sustain the quality and relevance in higher educational institutes (HEI) as well as in higher agricultural educational institutes (HAEI). In India, like NAAC under UGC, the accreditation is carried out in agricultural institutes in the three-tier system like degree programmes, college and university under the Indian Council of Agricultural Research (ICAR) by the National Agricultural Education Accreditation Board (NAEAB) with its secretariat. ICAR belongs to an autonomous organization of the Department of Agricultural Research and Education (DARE), Ministry of Agriculture and Farmers Welfare, Government of India. ICAR accreditation is a voluntary process and an institution and or different programmes can be accredited by more than one accreditation body. An agricultural college/university may be recognized first as schedule 2F/12B under UGC Act, along with Technology/ Engineering subjects by the National Board of Accreditation (NBA) of AICTE and Veterinary and Animal Sciences subjects by Veterinary Council of India (VCl). Being the non-statutory status, the ICAR does not provide the status "Recognition" or "Affiliation" to any organization/ institution/ university or any course/ programme/ degree offered by such institution but needs to comply with minimum requirement and academic regulations prescribed by ICAR. Accreditation is provided to an HAEI for five years and the mid-term review committee of NAEAB reviews the status of accreditation after completion of 2.5 years as post- accreditation monitoring process. Thus, the NAEAB accreditation is a recurring process and is intended to improve the marketability of students for national and international employment.
\end{abstract}

Key-words: AICTE, Accreditation, HAEI, ICAR, NAEAB, QMS

\section{INTRODUCTION}

Accreditation is the $3^{\text {rd }}$ party attestation related to an academic institute conveying the exhibition of its competence to carry out the specific predefined tasks about quality of education ${ }^{[1]}$. The quality of higher agricultural educational institutes is commonly inherent and provides value for money, conforms predefined specifications, meets customers like students and community needs, does right things first, have zero defect with the provision of academic eminence.

\section{How to cite this article}

Patra NC. Recent Advances in Accreditation Systems in Higher Agricultural Educational Institutes (HAEI) in India: A Review. SSR Inst. Int. J. Life Sci., 2021; 7(5): 2867-2883.
The institutional quality is measured by the different criteria like curricular aspects includes goal orientation, academic flexibility, curricular design and development, feedback on curriculum, curriculum update, professional and career development alongwith employability. The benchmarks for the criteria under teaching-learning and evaluation are transparency in the admission process, filling up a teaching position and experimental methodology, minimum 180 days of teaching days in an academic calendar, maximum use of ICT enabled teaching-learning, preference in $\mathrm{PhD}$ qualified staff recruitment with maximum time use of education technology as well as library resources. However, the research, innovation and innovation criteria include the key aspects like promotion of research, publication output, consultancy, collaboration and extension activities along with revenue generation. The infrastructure and learning resource criteria include 
physical facilities, maintenance of infrastructure, good library resource. Student support and progression criteria are student profile, student support and student facilities. However, the governance, leadership and management criteria possess effective and motivational initiatives, transparency in operation, decentralization of governance, the delegation of power, and willingness for reforms. The ultimate institutional value criteria are sensitive and changing demands for market and employability, sustainable quality and excellence [2]. Conformity Assessment Body (CAB) is a body that includes Testing including medical Laboratory, Calibration Laboratory, Proficiency Testing Provider, Certified Reference Material Producer, HEls, HAEls, institutes etc. The liberalization of trade and industry policies of the Government of India has created quality consciousness in domestic trade and provided greater thrust for quality. With the tune of this quality management in higher institutes, institutional accreditation has been started at the beginning of this $2000 A D$ and is regarded as a procedure by which a Government, non-Government or autonomous authoritative body recognizes the technical competence for specific institute/tests/measurements, based on third party assessment as per the international standards ${ }^{[3]}$.

Benefits of accreditation- Recognition of an educational institute has many advantages includes the educational institutions learn its strongness, weaknesses, and opportunities through an already-informed review process, identification of planning and resource allocation done internally, commensurations on the campus. At present, funding agencies commonly look for proper data for performance funding, institutions to initiate innovative as well as modern methods of pedagogy with a new sense of direction along with identity for institutions, reliable information on quality education provided ${ }^{[2,3]}$. Nowadays, employers look for reliable information on the quality education already offered to the prospective recruits, the intra and interinstitutional interactions along with the international recognition, focus given to global market, time and money efficiency, customers confidence and satisfaction, specific Quality Management System (QMS), continual improvements, better operational control, assurance of accurate and reliable results along with the continuation of quality, cost reduction and prevent loss due to defects.
Accreditation providers in India- The Quality Council of India $(\mathrm{QCl})$ are pioneer autonomous organizations of the Government of India to set up organizations in partnership with the Indian industry. Since 1992, a need perceived for the establishment of an accreditation body in the country to establish an internationally acceptable mechanism for recognition of conformity assessment results ${ }^{[4]}$. With regards to laboratories, an accreditation body under the Ministry of Science \& Technology (MoST) was already functioning. A committee formed which included various interested ministries and stakeholders including industries were established to make suitable recommendations. The work was coordinated by the then Department of Industrial Policy \& Promotion-DIPP, presently known as Department for Promotion of Industries and Internal Trade" (DPIIT) and the submitted recommendations were accepted to the Cabinet in $1996{ }^{[5]}$. Key recommendations were "the need for establishing an organization jointly by the Government and the industry" and "the need for the organization to be self-sustaining and be away from the Government". Receiving the recommendations, the Cabinet Committee decided to set up the Quality Council of India (QCI) as a non-profit autonomous society registered under Societies Registration Act XXI, 1860 to establish a genuine accreditation structure in the country and spread the quality movement in India by undertaking a National Quality Campaign. As depicted in the Governance structure above, $\mathrm{QCl}$ coordinates its activities through five constituent Boards briefed below [6].

NABCB- The National Accreditation Board for Certification Bodies allots accreditation to educational institutes based on the assessment of the organization's competence as per the Board's (NABCB) criteria and along with the specificities with International Standards and Guidelines. NABCB is an internationally recognized body ${ }^{[7]}$ and it represents the interests of the Indian present industry at international forums through active participation and memberships like MRA/ILAC.

NABET- NABET was initiated as the National Accreditation Board for Auditors and Training (NABAT), created in response to the emerging challenges in the conformity assessment arena. Its mandate is to establish and monitor the training and auditor's registration process. 
Subsequently, National Accreditation Board for Auditors and Training (NABAT) started to work as a registrar for auditors and training courses operating in conformity assessment areas such as Quality Management System (QMS), Environment Management System (EMS). Presently, it is called as National Accreditation Board for Education and Training (NABET) ${ }^{[8]}$.

NABL- National Accreditation Board for Testing and Calibration of Laboratories (NABL) furnishes accreditation in other terms recognition of technical competence of a Testing, Calibration (ISO 17025), Medical Laboratory (ISO 15189), Proficiency Testing Provider (PTP/ ISO 17043) and Reference Material Producer (RMP/ ISO 17034) for a specific scope of the laboratory following the international standards ${ }^{[9,10]}$.

NABH- The National Accreditation Board for Hospitals \& Healthcare Providers (NABH) also allots accreditation programmes for healthcare organizations. The board is concerned to cater to the much-desired needs of hospital consumers and preparing benchmarks for the progress of healthcare organizations ${ }^{[11]}$.

NBQP- National Board for Quality Promotion (NBQP) works on the mission of promoting the quality of life of the citizens of India. The Board organizes events i.e., Quality Conclaves (National/Regional/Virtual) and Quality Month Competitions ${ }^{[12] .}$
Teach-R Model (NCTE with QCI)- It is a new initiative of the National Council of Teacher Education (NCTE) for especially the B.Ed. institutes.

NAAC Model (UGC)- The National Assessment and Accreditation Council (NAAC) performs assessment and accreditation of Higher Educational Institutions (HEI) in India such as colleges, universities or other recognized institutions to estimate the 'Quality Status' of the institution. NAAC evaluates the applicant institutions for its conformance to the standards of quality in terms of grades on its performance related to the educational processes and outcomes, teaching-learning processes and their effectiveness, different curriculum coverage including new syllabus, faculty, research, infrastructure, organization, governance, different learning resources including E-learning, financial and student activities ${ }^{[13]}$.

NBA Model (AICTE)- The National Board of Accreditation was established by the All India Council of Technical Education (AICTE) in the year 1994 to assess the competence in engineering in dominance ${ }^{[14]}$.

NAEAB Model (ICAR)- It is used in the ICAR system of accreditation. The detail of the NAEAB is discussed below.

Table 1: Different accreditation body/ Statutory Body in India [15]

\begin{tabular}{|c|c|c|}
\hline S.No. & Council & Web Links \\
\hline 1. & All India Council of Technical Education- AICTE & http://www.aicte-india.org \\
\hline 2. & Medical Council of India - MCl & http://www.mciindia.org/ \\
\hline 3. & National Council for Teacher Education-NCTE & http://www.ncte-india.org/ \\
\hline 4. & Dental Council of India-DCI & http://www.dciindia.org/ \\
\hline 5. & Pharmacy Council of India-PCI & http://www.pci.nic.in/ \\
\hline 6. & Indian Nursing Council-INC & http://www.indiannursingcouncil.org/ \\
\hline 7. & Bar Council of India-BCl & http://www.barcouncilofindia.org/ \\
\hline 8. & Central Council of Homeopathy- $\mathrm{CCH}$ & http://www.cchindia.com/ \\
\hline 9. & Central Council for Indian Medicine-CCIM & http://www.ccimindia.org/ \\
\hline 10. & Council of Architecture-COA & http://www.coa.gov.in/ \\
\hline 11. & Distance Education Council-DEC & http://www.ugc.ac.in/deb/ \\
\hline
\end{tabular}


12.

13.

14.

15. National Councils of Education research \& training- NCERT

16. Institute of Chartered Accountants of India-ICAI

17. Institute of Cost \& Works Accountants of India-ICMAI

18. Institute of Company Secretaries of India-ICSI

19.
Rehabilitation Council of India-RCI

National Council for Rural Institutes-NCRI

Institution of Engineers http://rehabcouncil.nic.in/

http://www.ncri.in/

http://www.vci.nic.in/

http://www.ncert.nic.in/

http://www.icai.org/

http://icmai.in/icmai/index1.php/

http://www.icsi.edu/

http://www.ieindia.info/

Table 2: List of Research Councils in India providing funds for overall quality enhancement

\begin{tabular}{ccc}
\hline S. No. & Council & Web Links \\
\hline 1. & Council of scientific and Industrial Research (CSIR) & http://www.csir.res.in/ \\
2. & Department of Atomic energy (DAE) & http://www.dae.gov.in/ \\
3. & Defense Research and Development Organization (DRDO) & http://www.drdo.gov.in/ \\
4. & Indian Academy of Sciences (IAS) & http://www.ias.ac.in/ \\
5. & Indian National Academy of Engineering (INSE) & http://www.inae.org/ \\
6. & Indian Council for Agricultural Research (ICAR) & http://www.icar.org/ \\
7. & Indian Council of Historical Research (ICHR) & http://www.ichrindia.org/ \\
8. & Indian Council of Medical Research (ICMR) & http://www.icmr.nic.in/ \\
9. & http://www.icpr.in/ \\
10. & Indian Council for Philosophical Research (ICPR) & $\mathrm{http://www.icssr.org/}$ \\
11. & Indian Council for Social Sciences Research (ICSR) & $\mathrm{http://www.isro.org/}$ \\
12. & Indian National Science Academy (INSA) & http://www.insaindia.org/ \\
13. & National Academy of Sciences (NAS) & $\mathrm{http://nasi.nic.in/}$ \\
\hline
\end{tabular}

Indian Council of Agricultural Research (ICAR)- The Indian Council of Agricultural Research (ICAR) is an autonomous organisation of the Department of Agricultural Research and Education (DARE), Ministry of Agriculture and Farmers Welfare, Government of India. Previously, it was known as the Imperial Council of Agricultural Research, which was established on 16 July 1929 as a registered society under the Societies Registration Act, 1860 in pursuance of a report of the Royal Commission on Agriculture. The ICAR has its headquarters in New Delhi. The Council is the apex body for co-ordinating, guiding and managing research and education in agriculture including animal sciences and fisheries in the entire country. The ICAR boasts of having 101 numbers of ICAR institutes and 71 agricultural universities spread across the country like India. The ICAR has played a pivotal role in ushering Green Revolution and subsequent developments in agriculture in India through its research and latest technology development that has enabled the country to produce grains by 5.6 times, horticultural crops by 10.5 times, fish by 16.8 times, milk by 10.4 times and eggs by 52.9 times since $1950-51$ to $2017-18$, thus made a visible impact on the national food and nutritional security [16,17]. Simultaneously, it has played a major role in promoting excellence in higher education in agriculture. It is engaged in cutting edge areas of science and technology development along its scientists are internationally acknowledged in its fields. 
Table 3: Different ICAR Institutes in India

ICAR Deemed to be University

\begin{tabular}{ccc}
\hline S. No & Name of the Institutes & Places \\
\hline 1. & Indian Agricultural Research Institute & New Delhi \\
2. & National Dairy Research Institute & Karnal \\
3. & Indian Veterinary Research Institute & Izatnagar \\
4. & Central Institute on Fisheries Education & Mumbai \\
\hline
\end{tabular}

\section{Research Institutes under ICAR}

\begin{tabular}{|c|c|c|}
\hline S. No & Name of the Institutes & Places \\
\hline 1. & Central Island Agricultural Research Institute & Port Blair \\
\hline 2. & Central Arid Zone Research Institute & Jodhpur \\
\hline 3 & Central Avian Research Institute & Izatnagar \\
\hline 4. & Central Inland Fisheries Research Institute & Barrackpur \\
\hline 5 & Central Institute Brackish water Aquaculture & Chennai \\
\hline 6. & Central Institute for Research on Buffaloes & Hissar \\
\hline 7. & Central Institute for Research on Goats & Makhdoom \\
\hline 8. & Central Institute of Agricultural Engineering & Bhopal \\
\hline 9. & Central Institute for Arid Horticulture & Bikaner \\
\hline 10. & Central Institute of Cotton Research & Nagpur \\
\hline 11. & Central Institute of Fisheries Technology & Cochin \\
\hline 12. & Central Institute of Freshwater Aquaculture & Bhubaneswar \\
\hline 13. & Central Institute of Research on Cotton Technology & Mumbai \\
\hline 14. & Central Institute of Sub Tropical Horticulture & Lucknow \\
\hline 15. & Central Institute of Temperate Horticulture & Srinagar \\
\hline 16. & Central Institute on Post-harvest Engineering and Technology & Ludhiana \\
\hline 17. & Central Marine Fisheries Research Institute & Kochi \\
\hline 18. & Central Plantation Crops Research Institute & Kasargod \\
\hline 19. & Central Research Institute for Jute and Allied Fibres & Barrackpur \\
\hline 20. & Central Potato Research Institute & Shimla \\
\hline 21. & Central Research Institute of Dryland Agriculture & Hyderabad \\
\hline 22. & National Rice Research Institute & Cuttack \\
\hline 23. & Central Sheep and Wool Research Institute & Avikanagar \\
\hline 24. & Indian Institute of Soil and Water Conservation & Dehradoon \\
\hline 25. & Central Soil Salinity Research Institute & Karnal \\
\hline 26. & Central Tobacco Research Institute & Rajahmundry \\
\hline 27. & Central Tuber Crops Research Institute & Trivandrum \\
\hline 28. & ICAR-Research Complex for Eastern Region & Patna \\
\hline 29. & ICAR-Research Complex for NEH Region & Barapani \\
\hline 30. & Central Coastal Agricultural Research Institute & Goa \\
\hline 31. & Indian Agricultural Statistics Research Institute & New Delhi \\
\hline 32. & Indian Institute of Agricultural Biotechnology & Ranchi \\
\hline 33. & Indian Grassland and Fodder Research Institute & Jhansi \\
\hline 34. & Indian Institute of Horticultural Research & Bangalore \\
\hline 35. & Indian Institute of Natural Resins and Gums & Ranchi \\
\hline
\end{tabular}




\begin{tabular}{|c|c|c|}
\hline 36. & Indian Institute of Pulses Research & Kanpur \\
\hline 37. & Indian Institute of Soil Sciences & Bhopal \\
\hline 38. & Indian Institute of Spices Research & Calicut \\
\hline 39. & Indian Institute of Vegetable Research & Varanasi \\
\hline 40. & Indian Institute of Sugarcane Research & Lucknow \\
\hline 41. & National Academy of Agricultural Research \& Management & Hyderabad \\
\hline 42. & National Institute of Biotic Stresses Management & Raipur \\
\hline 43. & National Institute of Abiotic Stress Management & Malegaon \\
\hline 44. & National Institute of Animal Nutrition and Physiology & Bangalore \\
\hline 45. & National Institute of Natural Fibre Engineering and Technology & Kolkata \\
\hline \multirow[t]{2}{*}{46.} & National Institute of Veterinary Epidemiology and Disease & Bangalore \\
\hline & Informatics & \\
\hline 47. & Sugarcane Breeding Institute & Coimbatore \\
\hline 48. & Vivekananda Parvatiya KrishiAnusandhanSansthan & Almora \\
\hline 49. & Central Institute for Research on Cattle & Meerut \\
\hline 50. & National Institute of High-Security Animal Diseases & Bhopal \\
\hline 51. & Indian Institute of Maize Research & New Delhi \\
\hline 52. & Central Agroforestry Research Institute & Jhansi \\
\hline 53. & National Institute of Agricultural Economics and Policy Research & New Delhi \\
\hline 54. & Indian Institute of Wheat and Barley Research & Karnal \\
\hline 55. & Indian Institute of Millets Research & Hyderabad \\
\hline 56. & Indian Institute of Farming Systems Research & Modipuram \\
\hline 57. & Indian Institute of Oilseeds Research & Hyderabad \\
\hline 58. & Indian Institute of Oil Palm Research & Pedavegi \\
\hline 59. & Indian Institute of Water Management & Bhubaneswar \\
\hline 60. & Indian Institute of Rice Research & Hyderabad \\
\hline 61. & Central Institute for Women in Agriculture & Bhubaneswar \\
\hline 62. & Central Citrus Research Institute & Nagpur \\
\hline 63. & Indian Institute of Seed Research & Mau \\
\hline 64. & Indian Agricultural Research Institute & Hazaribagh \\
\hline 65. & National Institute for Plant Biotechnology & New Delhi \\
\hline
\end{tabular}

\section{National Research Centres (NRC) under ICAR}

\begin{tabular}{ccc}
\hline S. No. & Name of NRC & Places \\
\hline 1. & National Research Centre for Banana & Trichi \\
2. & National Research Centre for Grapes & Pune \\
3. & National Research Centre for Litchi & Muzaffarpur \\
4. & National Research Centre for Pomegranate & Solapur \\
5. & National Research Centre on Camel & Bikaner \\
6. & National Research Centre on Equines & Hissar \\
7. & National Research Centre on Meat & Hyderabad \\
8. & National Research Centre on Orchids & Pakyong \\
9. & National Research Centre on Mithun & Nagaland \\
10. & National Research Centre on Pig & Guwahati \\
11. & National Research Centre on Seed Spices & Ajmer \\
12. & National Research Centre on Yak & West Kemang \\
\hline
\end{tabular}



13.
National Centre for Integrated Pest Management
New Delhi
14.
Mahatma Gandhi Integrated Farming Research Institute
Motihari

\section{National Bureau under ICAR}

\begin{tabular}{ccc}
\hline S. No. & Name of National Bureau & Locations \\
\hline 1. & National Bureau of Plant Genetics Resources & New Delhi \\
2. & National Bureau of Soil Survey and Land Use Planning & Nagpur \\
3. & National Bureau of Agricultural Insect Resources & Bangalore \\
4. & National Bureau of Agriculturally Important Micro-organisms & Mau \\
5. & National Bureau of Animal Genetic Resources & Karnal \\
6. & National Bureau of Fish Genetic Resources & Lucknow \\
\hline
\end{tabular}

\section{Project Directorates under ICAR}

\begin{tabular}{ccc}
\hline S. No. & Name of Project Directorate & Place \\
\hline 1. & Directorate of Groundnut Research & Junagarh \\
2. & Directorate of Soybean Research & Indore \\
3. & Directorate of Rapeseed \& Mustard Research & Bharatpur \\
4. & Directorate of Mushroom Research & Solan \\
5. & Directorate on Onion and Garlic Research & Pune \\
6. & Directorate of Cashew Research, Puttur & Puttur \\
7. & Directorate of Medicinal and Aromatic Plants Research & Anand \\
8. & Directorate of Floricultural Research & Pune \\
9. & Directorate of Weed Research & Jabalpur \\
10. & Project Directorate on Foot \& Mouth Disease & Mukteshwar \\
11. & Directorate of Poultry Research & Hyderabad \\
12. & Directorate of Knowledge Management in Agriculture (DKMA) & New Delhi \\
13. & Directorate of Cold Water Fisheries Research & Bhimtal \\
\hline
\end{tabular}

As per instruction Ministry of Education, Government of India dated 13.10.2021, for maintenance of standards in higher education and research institutes, PhD degree will

Table 4: Different degree provided from agricultural university

be mandatory for direct recruitment to assistant professors in universities w.e.f. 01.07.2021.

\begin{tabular}{cccc}
\hline UG & PG & \multicolumn{2}{c}{ PhD } \\
\cline { 1 - 2 } Basic Science (Sc) & M.Sc & Subject wise \\
Plant Sc & M.Sc & Do \\
Social Sc & M.Sc & Do \\
Physical Sc & M. Stat. & Do \\
Statistical Sc & M.Sc & Do \\
Horticultural Sc & M.Sc & Do \\
Forestry Sc & M.Sc & Do \\
Home Sc & M. Tech & Do \\
Biotechnology & M.Sc & Do \\
Plant Protection & & Do
\end{tabular}




$\begin{array}{ccc}\text { Fishery Sc } & \text { M. F. Sc. } & \text { Do } \\ \text { Dairy Sc } & \text { M. Tech. } & \text { Do } \\ \text { Food Sc } & \text { M. Tech. } & \text { Do } \\ \text { Agricultural Engineering } & \text { M. Tech. } & \text { Do } \\ \text { Veterinary Sc } & \text { M.V.Sc. } & \text { Do }\end{array}$

process of accreditation (recognition), which is the main criteria for financial support ${ }^{[17]}$.

History of NAEAB- Following is the major developments are given below ${ }^{[3]-}$

In the year 1952, the Education Panel of ICAR proposed the development of model curricula of B.Sc. (Ag.) \& B.V.Sc and framed guidelines for the establishment of new agri-vet colleges. But in the year 1965, Standing Committee on Agricultural Education informed the Development of the first Model Act for different state agricultural university (SAU), agricultural engineering (Agri Engg), Agricultural and Veterinary subjects, Home Science subjects. Simultaneously, in the year 1974, the norms and accreditation committee reported the creation of norms towards financial assistance from ICAR for agricultural universities, different faculties in general universities and Private Colleges, who are offering degrees in Agriculture, veterinary, fishery, dairy, horticulture, home sciences after adopting the UGC pay scales by SAU, NET qualifications as mandatory and Career Advancement Schemes for promotion, development of various schemes for faculty members including competence improvement and developed a

Accreditation Board (1996)- The ICAR developed a process of accreditation in a comprehensive, rigorous and periodically improve quality and relevance of higher agricultural education in India. Though the accreditation board started its functions early, the accreditation Board was finally restructured with effect from $9^{\text {th }}$ February 2017. The Accreditation Board was modified to ensure the quality in various agricultural subjects of different agricultural universities and colleges in the country like in India. There are four regional centres of the NAEAB like (1)Indian Agricultural Research Institute (IARI), New Delhi (2) Central Research Institute for Jute and Allied Fibres (CRIJAF), Barrackpore, Kolkata (3) Central Institute for Fisheries Education (CIFE), Mumbai and (4) The Indian Institute of Horticultural Research, Bangalore are adhered to the NAEAB for accreditation of Higher Agricultural Educational Institutions (HAEIs) in India.

Table 5: Different Regional Offices of NAEAB

\begin{tabular}{|c|c|c|}
\hline Zones & Different states of India & Various Regional Offices \\
\hline North & $\begin{array}{c}\text { Haryana, Punjab, Rajasthan, Himachal Pradesh, Jammu \& Kashmir, } \\
\text { Uttar Pradesh, Uttarakhand, Chandigarh and Delhi }\end{array}$ & IARI, New Delhi \\
\hline $\begin{array}{l}\text { East and North } \\
\qquad \text { East }\end{array}$ & $\begin{array}{c}\text { Bihar, West Bengal (WB), Jharkhand, Assam, Manipur, Odisha, } \\
\text { Chhattisgarh (CG), Sikkim, Mizoram, Arunachal Pradesh, } \\
\text { Meghalaya, Nagaland, Andaman \& Nicobar Islands, Tripura }\end{array}$ & $\begin{array}{l}\text { CRIJ \& AF, } \\
\text { Barrackpore, near } \\
\text { Kolkata }\end{array}$ \\
\hline West & $\begin{array}{c}\text { Goa, Gujarat, Daman \& Diu, Madhya Pradesh (MP), Nagar Haveli, } \\
\text { Maharashtra }\end{array}$ & CIFE, Mumbai \\
\hline South & $\begin{array}{c}\text { Karnataka, Telangana, Kerala, Andhra Pradesh (AP), Tamil Nadu (TN) } \\
\text { and Pondicherry }\end{array}$ & IIHR, Bangalore \\
\hline
\end{tabular}

Table 6: Accreditation reforms period in India

\begin{tabular}{c}
\hline Years \\
\hline 1996
\end{tabular}

2004-2010

$2010-2014$

\section{Criteria's}

Establishment of Accreditation Board in ICAR

Accreditation was granted with general criteria without specified guidelines Benchmarks as IV Dean's report, BSMA report and ICAR Model Act. 
V Dean's report, BSMA report and ICAR Model Act and linking accreditation with development grant to the state agricultural universities (SAU), new introduction of scoring/grading points in accreditation processes and accreditation fee.

2018

$\checkmark$ Dean's report, BSMA report and ICAR Model Act and linking accreditation with development grant to state agricultural universities (SAU), the introduction of scoring/ grading points in the accreditation process and also with the allotment of all India seats in all accredited agricultural universities.

2020

2021 $\checkmark$ Dean's report, BSMA report and ICAR Model Act and linking accreditation with development grant to state agricultural universities (SAU), the introduction of scoring/ grading points in the accreditation process and also with the allotment of all India seats in all accredited agricultural universities and introduction of the online portal for accreditation of universities.

ICAR will act as a professional standard-setting body (PSSB) and provide required guidelines for all HAEIs both public and private institutes. Veterinary Council of India $(\mathrm{VCl})$ will act to provide the professional standard for veterinary education. Deemed universities of ICAR will be transformed into Multidisciplinary Education and Research Institute (MERU). NAEAB may be recognized as accreditor for accreditation of different agricultural programmes, College and University offering agricultural education under the National Accreditation Council (NAC) under NEP, 2020.

\section{Accreditation fees amount for NAEAB application for} accreditation- The fees commonly collected from Applicant College or faculty are entirely exhausted during accreditation process at different levels including Board Secretariat, Regional Centres [16], Peer Review Teams, Post-accreditation monitoring and review and completing other requirements of the Board in efficient, time-bound ways. The fees are of three types:

1. Rs 6.0 lakh + GST for Accreditation of the different Agricultural University plus constituent colleges plus programmes.

2. Rs 3.0 lakh + GST for accreditation of Agricultural College (s).

3. Rs 2.0 lakh + GST for accreditation of Academic Programmes irrespective of the number of programmes for accreditation.

However, expenditure for conduction of Peer Review for accreditation is to be borne by applicant colleges or universities.

The eligibility criteria for NAEAB application- HAEls may apply for the accreditation from the NAEAB; ICAR when at least one batch has passed out from college and fulfils all other criteria laid in different provisions. The eligibility criteria of HAEls are grouped as below:

Agricultural Universities- Different State Agricultural Universities (SAUs), State Veterinary Universities, Central
Agricultural Universities (CAU), State Horticultural Universities, State Fisheries Universities and ICAR Deemed-to-be-Universities (DU) etc ${ }^{[3,17]}$ may apply for ICAR accreditation.

Agricultural Colleges (also termed as Schools, Faculties, Institutes)- Autonomous, constituent and affiliated agricultural colleges (offering Degree Programmes in agriculture and allied sciences subjects) in State Agricultural Universities (SAU), State Horticultural Universities, State Veterinary Universities, State Fishery Universities, Central Agricultural Universities (CAU), ICAR Deemed Universities, Private Universities, State Universities, Central Universities, UGC Deemed Universities and others ${ }^{[3,18]}$.

Academic Programmes- Different Bachelor (UG), Master (PG) and PhD. Degree Programmes in agriculture and allied science subjects as per the recommendation of Deans' Committees, Veterinary Council of India ( $\mathrm{VCl}$ ) and Broad Subject Matter Area (BSMA) Committees of ICAR for various Agricultural Universities and Colleges are eligible for accreditation through NAEAB ${ }^{[3,19]}$.

Latest Format for scoring of NAEAB accreditationDifferent Agricultural Universities boast having constituent Colleges depicted under ICAR Model Act (2009 revised) and are established following the broad 
guidelines outlined by ICAR Model Act. Besides the Colleges and various disciplines, the Agricultural University should adopt strong networks of research centres, KVKs and other extension units set up which are required for effective agricultural education [20,21]. Different colleges, research stations, KVKs and other units should have the status as constituent colleges under university with the same authoritative control. However, none unit shall be recognized as an affiliated unit ${ }^{[22,23]}$. At present, the NAEAB follows the below mentioned.

Table 7: Criteria, key aspects and pre-determined weightage for Agricultural University M accreditation ${ }^{\text {[24-26] }}$

\begin{tabular}{|c|c|c|c|c|c|}
\hline Criteria & & Key Aspects & $\begin{array}{c}\text { Pre- } \\
\text { determined } \\
\text { Weightage } \\
\text { (W) }\end{array}$ & $\begin{array}{c}\text { Peer Review } \\
\text { Team } \\
\text { providing } \\
\text { Key Aspect } \\
\text { Grade points } \\
\text { (KAGP) } \\
(4 / 3 / 2 / 1 / 0)\end{array}$ & $\begin{array}{l}\text { Key Aspect } \\
\text { based } \\
\text { Weighted } \\
\text { Grade Point } \\
\text { (KAWGP) }\end{array}$ \\
\hline \multirow{12}{*}{$\begin{array}{l}\text { 1. Gover- } \\
\text { nance }\end{array}$} & $1 a$. & Vision, Mission and Goals of applicant & 40 & 3 & 120 \\
\hline & 1b. & Statutes and Regulations & 40 & 2 & 80 \\
\hline & 1c. & University Statutory Officer Selection & 50 & 3 & 150 \\
\hline & & Process as per the Statutes of the University & & & \\
\hline & $1 \mathrm{~d}$ & Decentralization of Powers of institutes & 30 & 1 & 30 \\
\hline & $1 \mathrm{e}$. & $\begin{array}{l}\text { Supporting Units (Maintenance Cell / SC/ } \\
\text { ST Cell/ Health Centre) }\end{array}$ & 30 & 4 & 120 \\
\hline & $1 \mathrm{f}$. & Technology Support & 20 & 1 & 20 \\
\hline & $1 g$. & Institutional Database + Website update & 20 & 2 & 40 \\
\hline & 1h. & Inter-Departmental Linkages & 20 & 0 & 0 \\
\hline & 1i. & Monitoring Mechanism & 30 & 1 & 30 \\
\hline & 1j. & Institute Quality Assurance Cell / PME Cell & 30 & 2 & 60 \\
\hline & $1 \mathrm{k}$. & $\begin{array}{l}\text { Collaboration with relevant Academic Institutions } \\
\text { and Industry }\end{array}$ & 40 & 3 & 120 \\
\hline Sub-total & & $(1 \mathrm{a}+\ldots+1 \mathrm{k})$ & $W_{1}=350$ & & $\begin{array}{l}(\text { KAWGP)i } \\
=770\end{array}$ \\
\hline 2. & $2 a$. & Academic Council & 30 & & \\
\hline Academic & $2 b$. & Innovations and Best Practices & 30 & & \\
\hline \multirow[t]{7}{*}{ Support } & $2 c$. & Library/CLINS & 100 & & \\
\hline & $2 \mathrm{~d}$ & $\begin{array}{c}\text { Centre for Excellence/ Advance Studies/ Centre for } \\
\text { Advanced Faculty Training (CAFT)etc }\end{array}$ & 20 & & \\
\hline & $2 e$. & Incubation Centre & 30 & & \\
\hline & $2 f$. & Technology Enabled Learning Resources & 10 & & \\
\hline & $2 \mathrm{~g}$. & $\begin{array}{l}\text { Integrated Learning System } \\
\text { (Experiential Learning) }\end{array}$ & 10 & & \\
\hline & $2 \mathrm{~h}$. & Academic- Industry Interface & 10 & & \\
\hline & $2 \mathrm{i}$. & National Ranking (ICAR/MHRD) & 10 & & \\
\hline Sub-total & & $(2 \mathrm{a}+\ldots+2 \mathrm{i})$ & $W_{I I}=250$ & & $(K A W G P)_{\|}$ \\
\hline 3. & 3a. & Research Council/REEC & 20 & & \\
\hline Research & $3 b$. & Directorate of Research/DREF & 20 & & \\
\hline Support & 3c. & Technologies Developed and their Adoption & 40 & & \\
\hline
\end{tabular}


3d. Research Publications (based on the work carried out in University)

$3 e$.

Citation Index/ $h$ Index

$3 f$.

$3 g$.

3h.

$3 i$.

$3 \mathrm{j}$.

\section{Sub-total}

4.

Extension

Support

$4 a$.

$4 \mathrm{~b}$.

Innovations and Best Practices
IPR Cell / ITMU
Central Instrumentation Unit
Global Support
CSR Funding

$(3 a+\ldots+3 j)$

Extension Council/REEC

4c. Extension Planning and Technological Impact

4d. Implementation of National initiatives

4 e. Innovations and Best Practices

$4 f$.

$$
\begin{gathered}
\text { Consultancy/Certification /Testing } \\
\qquad(4 a+\ldots+4 f)
\end{gathered}
$$

\section{Sub-total}

5. Faculty and staff

Developm

ent

$5 a$.

Recruitment and Promotional Avenues/CAS

$5 b$.

Participation of Faculty in National and International Seminars/Workshops/Symposia

5c. Incentives to Excellence/Faculty Recognition

5d. Capacity Building and Training /CBP

\section{Sub-total}

6. Student Developm ent

$6 a$.

$$
(5 a+\ldots+5 d)
$$

Scholarships / Stipend

$6 b$.

$6 c$.

Extra and Co-curricular Activities

$$
\text { Health Insurance }
$$

$6 d$.

Sports and Cultural Facilities

$6 e$.

$$
\text { Student Counseling and Placement Cell }
$$

$6 f$.

$$
\text { Disabled Friendly Ability }
$$

$$
(6 a+\ldots+6 f)
$$

7. Infrastructure
7a.

$$
\begin{aligned}
& \text { Physical Facilities Including Administrative Build } \\
& \text { and Necessary Land preferably own land }
\end{aligned}
$$

$7 b$.

IT Infrastructure

7c.

$$
\text { Student and Staff Amenities }
$$

\section{Sub-total}

8. Financial

Resource

Managemen

$t$

$8 a$.

$$
(7 a+7 b+7 c)
$$

$$
\text { Budget allocation (Salary: Contingency) }
$$

$8 \mathrm{~b}$.

Finance Committee

$$
\text { Internal Resource Generation }
$$

8d. Resource Mobilization through External Funding

8e. Financial delegation to Deans and HoDs and others

8f. Per cent finance utilization in last five years

Sub-total

9. Accomplish ments

$$
(8 \mathrm{a}+\ldots+8 \mathrm{f})
$$

9a. Regional, National, International Awards of the University

9b. Accreditation from ICAR/Other Agencies and

Follow up on its Recommendations

\section{5}

15

20

20

20

10

10

$\mathrm{W}_{\text {III }}=200$

20

20

50

25

25

10

$\mathrm{W}_{\mathrm{IV}}=150$

$\mathrm{W}_{\mathrm{V}}=200$

$W v_{i}=250$

$W_{\text {vii }}=150$

$w_{\text {viii }}=200$
50

60

40

50

$(K A W G P) V$

40

40

30

50

60

30

100

25

25

40

20

50

50

20

20

50

(KAWGP) VIII

$($ KAWGP) IV

(KAWGP) VI

$($ KAWGP) VII 


\begin{tabular}{|c|c|c|c|c|}
\hline & 9c. & Inter Institutional Standing & 25 & \\
\hline & $9 d$. & Socio-economic Impact & 25 & \\
\hline & 9e. & International Collaboration & 50 & \\
\hline & 9f. & Fund Raising Through CSR & 25 & \\
\hline & $9 g$. & Alumni Support & 25 & \\
\hline Sub-total & & $(9 a+\ldots+9 g)$ & $\mathrm{W}_{\mathrm{ix}}=250$ & $($ KAWGP) ix \\
\hline Total of C & & & $\begin{array}{c}(\mathrm{w})_{\mid-i x} \\
=2000\end{array}$ & $\square(\mathrm{CrWGP})_{\mid-\mathrm{ix}}=6500$ \\
\hline \multicolumn{3}{|c|}{ CGPAU of the University $=\left(\square(\text { CrWGP })_{\mid-i x}\right) / W_{\mid-i x}$} & \multicolumn{2}{|c|}{$6500 / 2000=3.25$} \\
\hline
\end{tabular}

The Grade point average for the agricultural university (GPAAU)- The NAEAB has made nine criteria like governance, academic support, research support, extension support, faculty and staff development, student development, infrastructure, financial resource development and accomplishment. Under each criterion, there are varieties of key aspects along with predetermined weightage. The PRT assigns $0 / 1 / 2 / 3 / 4$ points against each key aspect without any decimal. By the use of the guiding indicators and based on actual observations and assessment of the institution (on-spot visit as well as the SSR validation), the Peer Review Team judiciously assign accurate grade points to each of the key aspecton5 point scale (0, 1, 2, 3 and 4). The Key Aspect-wise Weighted Grade Point (KAWGP) is calculated by multiplying the Predetermined Weightage (W) of each Key Aspect with the corresponding Key Aspect Grade Point (KAGP). The predetermined weightage is fixed that is 2000 at present ${ }^{[27]}$. The sum of KAWGP is calculated by considering all nine criteria.

\section{Grading as well as accreditation of already applicant} University- There are four types of grades like A+, A, B and $C$ given to any accredited university. The mean of all colleges under a university is termed as $G_{C}$ in the grading system. However, the $G_{u}$ will be the score of the concerned university.

The final grading of the university $\left(G_{f}\right)$ will be $G_{f}=$ $\left(G_{c}+G_{u}\right) / 2$, When the score $G_{f}$ is 2.49 or lower, it is treated that the university is not accredited.
Table 8: Different Grade's corresponding to university score

\begin{tabular}{cc}
\hline University Score $\left(\mathrm{G}_{\mathrm{f}}\right)$ & Grade \\
\hline 3.50 or more & $\mathrm{A}+$ \\
$3.00-3.49$ & $\mathrm{~A}$ \\
$2.75-2.99$ & $\mathrm{~B}$ \\
$2.50-2.75$ & $\mathrm{C}$ \\
2.49 or less & Nil/Not accredited \\
\hline
\end{tabular}

Post-Accreditation monitoring-The HAEI have to submit a comprehensive compliance report in a published format prescribed for Peer Review Team, NAEAB for accreditation of the institution after completion of 2.5 years from the date of accreditation. The compliance report shall be reviewed by the Sectoral Committees/ Mid-term Review Committee of NAEAB, New Delhi. Commitments made by universities through undertaking by Registrar office order. Letters to the PRT chairman or in the mid of observation of peer review may be verified along with the observations made during grant of accreditation of applicant ${ }^{[28-30]}$. Observation of the Committees shall be put up to the next meeting, NAEAB for decision.

Online portal- In order to infuse transparency and efficiency in the accreditation process, the NAEAB decided to implement an online mode process for the invitation of Lol/IEA/Statement of Compliance as well as its preliminary examination. The Indian Agricultural Statistics Research Institute (IASRI), New Delhi under the National Agricultural Higher Education Project (NAHEP) developed the portal (https://accreditation.icar.gov.in/) and it's Standard Operating Procedure along with the following three Manuals which are available on the Accreditation Portal. 

i. User Manual for NAEAB, Secretariat
ii. User Manual for Regional Centres, NAEAB
iii. User Manual for Registrars of applicant Universities

Table 9: Steps in the NAEAB accreditation process

\begin{tabular}{|c|c|}
\hline Steps & Functions \\
\hline First (1) & $\begin{array}{l}\text { Online submission of Letter of Intent (Lol), Institutional Eligibility for Accreditation (IEA) and } \\
\text { Statement of Compliance (SoC) to NAEAB Secretariat } \\
\text { Within } 15 \text { Days }\end{array}$ \\
\hline Second (2) & $\begin{array}{l}\text { Applicant HAEl is communicated by NAEAB } \\
\text { Within } 30 \text { Days }\end{array}$ \\
\hline Third (3) & Self Study Report (SSR) to Regional Centre of the concerned HAEI and Fees to NAEAB deposited \\
\hline & Within 15 Days \\
\hline Fourth (4) & $\begin{array}{l}\text { Peer Review Team (PRT) formed by NAEAB } \\
\text { Within } 30 \text { Days }\end{array}$ \\
\hline Fifth (5) & PRT visits HAEl and submits reports to NAEAB \\
\hline Sixth (6) & Accreditation to HAEI by NAEAB for five years \\
\hline & After 2.5 years of date of accreditation to HAEI \\
\hline Seventh (7) & Comprehensive Compliance Report by HAEI to NAEAB \\
\hline Eighth (8) & Accreditation continued next 2.5 years. \\
\hline
\end{tabular}

Table 10: Ranking of different HAEls as for 2019 published on 05.12 .2020 by ICAR

\begin{tabular}{cc}
\hline S. No. & Name of the HAEI under ICAR \\
\hline 1 & ICAR-National Dairy Research Institute, Karnal \\
2 & Punjab Agricultural University, Ludhiana \\
4 & ICAR-Indian Agricultural Research Institute, New Delhi \\
5 & ICAR-Indian Veterinary Research Institute, Izatnagar \\
6 & G B Pant University of Agriculture \& Technology, Pantnagar \\
7 & Chaudhary Charan Singh Haryana Agricultural University, Hisar \\
8 & Guru Angad Dev Veterinary and Animal Sciences University, Ludhiana \\
9 & Tamil Nadu Agricultural University, Coimbatore \\
10 & University of Agricultural Sciences, Dharwad \\
11 & Professor Jayashankar Telangana State Agricultural University, Hyderabad \\
12 & Dr. Yaswant Singh Parmar University of Horticulture \& Forestry, Nauni-Solan \\
13 & Sher-e-Kashmir University of Agricultural Sciences and Technology of Kashmir, Srinagar \\
14 & Acharya N.G. Ranga Agricultural University, Guntur \\
15 & Ch. Sarwan Kumar Krishi Vishvavidyalaya, Palampur \\
16 & Bidhan Chandra Krishi Viswavidyalaya, Nadia, WB \\
17 & ICAR-Central Institute of Fisheries Education, Mumbai \\
18 & Sardar Vallabhbhai Patel University of Agriculture and Technology, Meerut \\
19 & University of Agricultural Sciences, Bangalore \\
20 & Kerala Agricultural University, Thrissur \\
\hline & Orissa University of Agricultural and Technology, Bhubaneswar \\
\hline
\end{tabular}




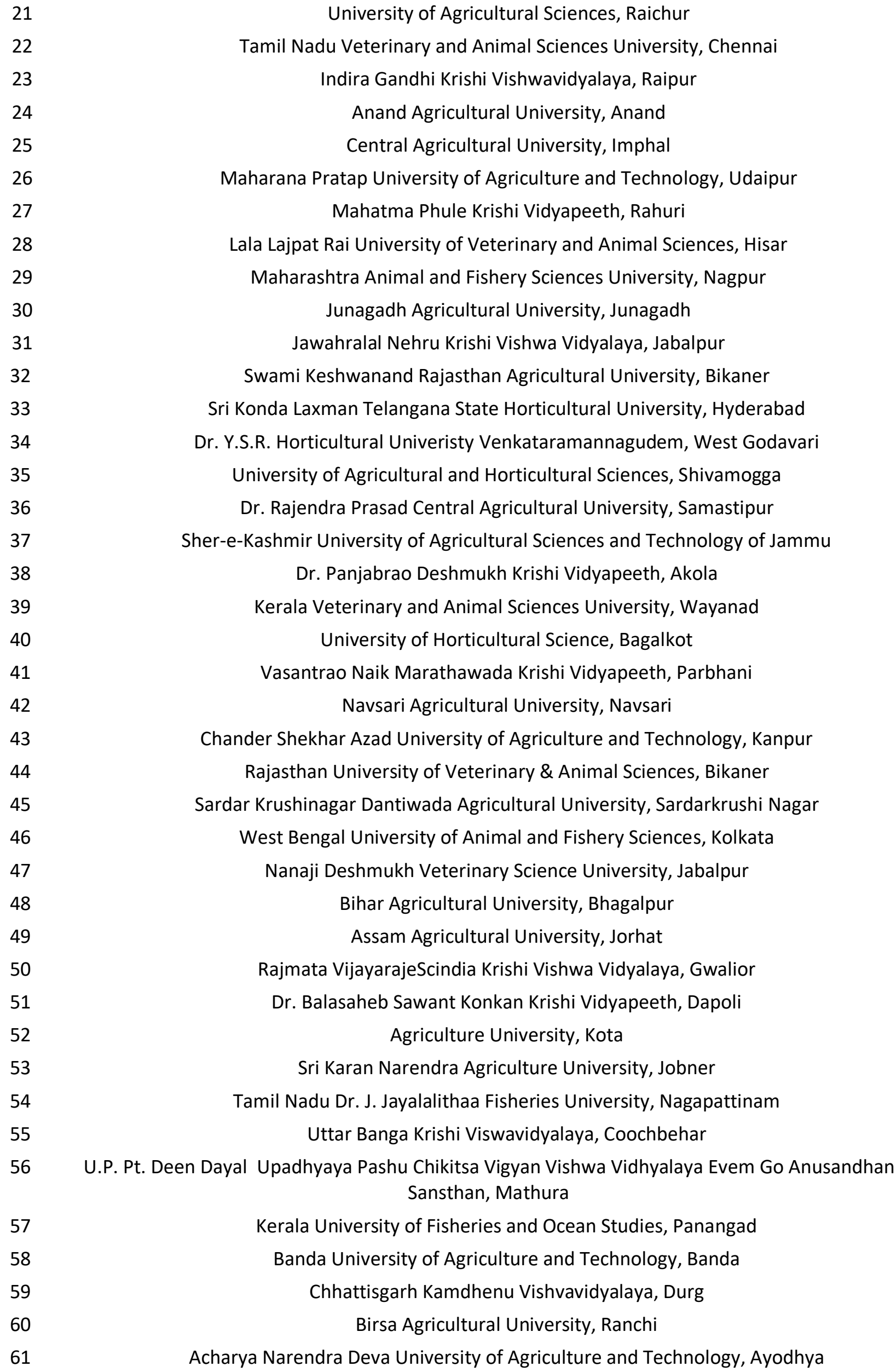

University of Agricultural Sciences, Raichur

Tamil Nadu Veterinary and Animal Sciences University, Chennai Indira Gandhi Krishi Vishwavidyalaya, Raipur

Anand Agricultural University, Anand

Central Agricultural University, Imphal

Maharana Pratap University of Agriculture and Technology, Udaipur Mahatma Phule Krishi Vidyapeeth, Rahuri Lala Lajpat Rai University of Veterinary and Animal Sciences, Hisar Maharashtra Animal and Fishery Sciences University, Nagpur Junagadh Agricultural University, Junagadh Jawahralal Nehru Krishi Vishwa Vidyalaya, Jabalpur Swami Keshwanand Rajasthan Agricultural University, Bikaner Sri Konda Laxman Telangana State Horticultural University, Hyderabad Dr. Y.S.R. Horticultural Univeristy Venkataramannagudem, West Godavari University of Agricultural and Horticultural Sciences, Shivamogga Dr. Rajendra Prasad Central Agricultural University, Samastipur Sher-e-Kashmir University of Agricultural Sciences and Technology of Jammu Dr. Panjabrao Deshmukh Krishi Vidyapeeth, Akola Kerala Veterinary and Animal Sciences University, Wayanad University of Horticultural Science, Bagalkot Vasantrao Naik Marathawada Krishi Vidyapeeth, Parbhani Navsari Agricultural University, Navsari Chander Shekhar Azad University of Agriculture and Technology, Kanpur Rajasthan University of Veterinary \& Animal Sciences, Bikaner Sardar Krushinagar Dantiwada Agricultural University, Sardarkrushi Nagar West Bengal University of Animal and Fishery Sciences, Kolkata Nanaji Deshmukh Veterinary Science University, Jabalpur Bihar Agricultural University, Bhagalpur Assam Agricultural University, Jorhat Rajmata VijayarajeScindia Krishi Vishwa Vidyalaya, Gwalior Dr. Balasaheb Sawant Konkan Krishi Vidyapeeth, Dapoli Agriculture University, Kota Sri Karan Narendra Agriculture University, Jobner Tamil Nadu Dr. J. Jayalalithaa Fisheries University, Nagapattinam Uttar Banga Krishi Viswavidyalaya, Coochbehar U.P. Pt. Deen Dayal Upadhyaya Pashu Chikitsa Vigyan Vishwa Vidhyalaya Evem Go Anusandhan Sansthan, Mathura Kerala University of Fisheries and Ocean Studies, Panangad Banda University of Agriculture and Technology, Banda Chhattisgarh Kamdhenu Vishvavidyalaya, Durg Birsa Agricultural University, Ranchi Acharya Narendra Deva University of Agriculture and Technology, Ayodhya 
Karnataka Veterniary, Animal and Fisheries Sciences University, Bidar

Agriculture University, Jodhpur

Sri Venkateswara Veterinary University, Tirupati

Uttarakhand University of Horticulture \& Forestry, Bharsar

Bihar Animal Sciences University, Patna

\section{Accreditation of agri-education in National Educational}

Policy-2020 (NEP-2020)- The aim is to increase the gross enrollment ratio in higher education from $26.30 \%$ (2018) to $50 \%$ by $2035^{[31-33]}$. All the standalone agricultural universities will be multidisciplinary to increase agricultural productivity through better-skilled graduates and technicians, innovative research, market-based extension linked to technology and practices for direct local community development. All professional students should learn artificial intelligence, 3-D monitoring, big data analysis, genome studies, biotechnology, nanotechnology, neuroscience etc. The regulatory authority will be the Higher Education Commission in India (HECl) under the Department of Education, Govt. of India ${ }^{[34,35]}$. The first vertical of $\mathrm{HECl}$ will be the National Higher Education Regulatory Council (NHERC) as a common, single point regulator, second vertical National Accreditation Council (NAC) for accreditation of higher education institutes, third vertical Higher Education Grants Council (HEGC) for funding and financing and fourth vertical General Education Council for evaluation of learning outcome [36] through National Higher Education Qualification Framework (NHEQF). Simultaneously, the professional councils in agriculture like the Indian Council of Agricultural Research (ICAR), Veterinary Council of India ( $\mathrm{VCl}$ ) and proposed Fishery Council of India ( $\mathrm{FCl}$ ) will act as professional standardsetting bodies (PSSBS).

\section{CONCLUSIONS}

In higher education institutes, there are models like Baldridge model, ISO-9001, Capacity maturity model, Six Sigma, Total quality management, Kaizen model, Bennett's quality model, Servqual model and balanced scorecard where no one is complete in the accreditation system. Few organizations undergo two or more accreditation systems instead of single accreditation. In higher educational institutes, NAAC is under UGC, NBA under AICTE and Teach-R model for NCTE with the collaboration of $\mathrm{QCl}$ are used in different institutes. But in agricultural institutes, till today, only the NAEAB performs accreditation to evaluate its global acceptance. Few courses under the ICAR system need NBA/AICTE accreditation (Technology/Engineering), $\mathrm{VCl}$ recognition (Veterinary Science) and different laboratory need NABL accreditation (ISO 17025: 2017) along with overall institute quality management system (ISO 9001:2015). Future will say whether there is a need for so many accreditations or single accreditation for higher agricultural educational institutes in India as well as the world.

\section{ACKNOWLEDGMENTS}

The author is thankful to the West Bengal University of Animal and Fishery Sciences, Kolkata, India for providing the necessary facilities to prepare the manuscript.

\section{CONTRIBUTION OF AUTHORS}

One author is only contributed in this article.

\section{REFERENCES}

[1] UNESCO. Policy paper for change and development in higher education. United Nations Educational Scientific and Cultural Organization. Paris, France, 1995; pp. 44.

[2] Varghese MA, Katre S, Reddy SR, Sharma SC. Quality Management System. $1^{\text {st }}$ ed. Hyderabad; NAAC, 2020; pp. 80-93.

[3] Agarwal RC, Venkateshwarlu G, Tripathi, KP. Policy paper on quality assurance in higher agricultural education through accreditation by national agricultural educational accreditation board. $1^{\text {st }}$ ed., ICAR publication, India, 2021; pp. 13-16.

[4] Dwivedi VJ, Joshi YC. Productivity in $21^{\text {st }}$ century Indian higher education institutions. Int J Human Resource Mngt Res., 2019; 9(4): 61-80.

[5] Prasad RK, Jha MK. Quality measures in higher education: a review and conceptual model. J Res Business Mngt., 2013; 5(3): 23-40. 
[6] qcin.org [Internet] New Delhi: Quality Council of India,Available from https;//www.qcin.org/. Updated at 2021. Accessed August 8, 2021.

[7] nabcb.qci.org.in [Internet] New Delhi: National Accreditation Board for Certification Body. Available from: https//www.nabcb.qci.org.in/. Updated at 2021. Accessed August 8, 2021.

[8] nabet.qcin.org [Internet] New Delhi: National Accreditation Board for Education and Training. Available from: https//www.nabet.qcin.org.in/. Updated at 2021. Accessed August 8, 2021.

[9] nabl-india.org [Internet] New Delhi: National Accreditation Board for Testing and Calibration Laboratory. Available from https//www.nablindia.org/. Updated at 2021. Accessed August 8, 2021.

[10]Patra NC, Mukhopadhayay SK. Laboratory accreditation in India including latest ISO/IEC 17025; 2017: an overview. Ind J Pathol Onchol., 2019; 6(1): 1-8.

[11]nabh.co [Internet] New Delhi: National Accreditation Board for Hospitals and Healthcare Management. Available from: https//www.nabh.co/. Updated at 2021. Accessed August 8, 2021.

[12]nbqp.qci.org.in [Internet] New Delhi: National Accreditation Board for Quality Promotion. Available from: https//www.nbqp.qci.org.in/. Updated at 2021. Accessed August 8, 2021.

[13]naac.gov.in [Internet] New Delhi: National Assessment and Accreditation Council. Available from https//www.naac.gov.in/. Updated at 2021. Accessed August 8, 2021.

[14]nbaind.org [Internet] New Delhi: National Board of Accreditation. Available from https//www.nbaind. org/. Updated at 2021. Accessed August 8, 2021.

[15]ugc.ac.in [Internet] New Delhi: University Grants Commission. Available from https//ugc.ac.in/page/ professional-councils.aspx/. Updated at 2021. Accessed August 8, 2021.

[16]icar.org.in [Internet] New Delhi: Indian Council of Agricultural Research. Available from https;///icar.org.in/content/national-agriculturaleducation-accreditation board/. Updated at 2021. Accessed August 8, 2021.

[17]Rathore NS, Venkateshwarlu G, Tripathi KP. Guidelines for accreditation of higher agricultural educational institutes in India. New Delhi; ICAR, 2017; pp. 26-29.

[18]Sharma HL, Tiwari R, Anju BZ. Management of higher education institutions: issues and challenges. Int J Busi Eco Mngt Res., 2013; 3(2): 275-84.

[19]Srikanthan G, Dalrymple JF. Developing alternative perspectives for quality in higher education. Int J Edu Mngt., 2003;17(3): 126-36.

[20]Agarwal P. Higher education in India: Growth, concerns and change agenda. Higher Edu Quarterl., 2007; 61(2): 197-07.

[21]Brar A. How higher education in India is transforming into broader education. Hindustan Times., 2019; published on $2^{\text {nd }}$ January.

[22] Sharma S, Sharma A. Indian higher education system: Challenges and suggestions. Elect J Inclu Edn., 2015; 3(4): 3-4.

[23]Sheikh YA. Higher education in India: Challenges and opportunities. J Edu Prac., 2017; 8(1): 39-42.

[24]Wats M, Wats RK. Enhancing quality of higher education through comprehensive continuous evaluation. Int. J. Cross-Disciplinary Subjects Edu. 2013; 2(4): 1172-79.

[25]NITI Aayog. Strategy for new India@75.2015; https://niti.gov.in/strategy-new-india-75.

[26]Rashtriya Uchchatar Shiksha Abhiyan (RUSA). Ministry of Human Resources Development, Govt of India. 2020; June. Available from: https://mhrd.gov.in/en/rusa.

[27]Varghese MA, Katre S, Reddy SR. Dynamics of Indian higher education. Abhishek Publications, 2019.

[28]Audin K, Davy J, Barkham M. University quality of life and learning (UniQoLL): An approach to student well being, satisfaction and institutional changes. J Further Higher Edu., 2003; 27(4): 365-82.

[29]Dey N. Higher education institutions in India and its management. Int J Acad Res Business Social Scs., 2011; 1(1): 20-28.

[30]Flavin M. Disruptive technologies in higher education. Res Learning Tech., 2012; 20: 102-11.

[31]Ludeman RB, Osfield KJ, Hidalgo El, Oste D, Wang HS. Student affairs and services in higher education: Global foundations, issues and best practices. UNESCO, 2009. Varghese MA, Kumar S. E-assessment for large volume assessment and accreditation. University news, 2017; 55(17): 10-14. 
[32]Ramaswamy $M$, Vilvarayanallur $M$, Maheswari A, Kalyanaraman $S$, Srinivasan $S$, Mani T. Enhancing quality of education in India by 2030. A F.I.T. approach to realizing SDG 4. KPMG. Available from: https://assets.kpmg/content/dam/kpmg/in/pdf/201 9/11/enhancing quality of education in India by 2030.pdf.

[33]Varghese MA, Kumar S. E-assessment for large volume assessment and accreditation. University news, 2017; 55(17): 10-14.
[34]Dwivedi VJ, Joshi YC. Productivity in $21^{\text {st }}$ century Indian higher education institutions. Int J Human Resource Mngt Res., 2019; 9(4): 61-80.

[35]Madhan M, Gurusekaran S, Arunachalam S. Evaluation of research in India; Are we doing it right? Ind J Med Ethics, 2018; 3(3): 221-29.

[36] Pal Y. Report of the "Committee to advice on renovation and rejuvenation of higher education, 2019. Available from: https://www.aicte-india.org/ downloads/yashpal-committee-report.pdf. 